\title{
Teachers' Beliefs, Perceived Practice and Actual Classroom Practice in Relation to Traditional (Teacher-Centered) and Constructivist (Learner-Centered) Teaching (Note 1)
}

\author{
Sibel Ersel Kaymakamoğlu ${ }^{1}$ \\ ${ }^{1}$ European University of Lefke, Dr. Fazıl Küçük Faculty of Education, Lefke, Turkey \\ Correspondence: Sibel Ersel Kaymakamoğlu, European University of Lefke, Dr. Fazıl Küçük Faculty of \\ Education, Lefke, Mersin 10, Turkey. E-mail: sibelkaymakamoglu@gmail.com
}

Received: August 19, 2017

Accepted: August 30, $2017 \quad$ Online Published: September 4, 2017

doi:10.5539/jel.v7n1p29

URL: https://doi.org/10.5539/jel.v7n1p29

\begin{abstract}
This study explored the EFL teachers' beliefs, perceived practice and actual classroom practice in relation to Traditional (teacher-centered) and Constructivist (learner-centered) teaching in Cyprus Turkish State Secondary Schools context. For this purpose, semi-structured interviews and structured observations were employed with purposively selected participants to gain in-depth understanding about the teachers' beliefs, their perceived practice and actual classroom practice. The teachers were interviewed to elicit their subjective views about their beliefs and perceived practice regarding the themes, teacher-centered and learner-centered teaching in the context of their instructional practice. The observations were carried some time after the interviews had been completed. The teachers were observed for the purpose of exploring to what extent their beliefs were reflected in their classroom practice. COLT (Communicative Orientation of Language Teaching) Observation Scheme was utilized as the data collection instrument. 10 EFL teachers were purposively selected by criterion sampling as the participants of the investigation. An equal number of experienced male and female teachers who were similar in terms of length of experience were selected for the in-depth interviews and observations on voluntary basis. Findings of the study revealed that regarding teacher-centered and learner-centered teaching, teachers showed some variations in their stated beliefs. The interview data indicated that although the teachers expressed their beliefs in Constructivist learning and teaching, and both Constructivist and Traditional, their perceived practice was Traditional (except one teacher for whom it was both). However, the findings based on the observational data showed that Traditional practice was more frequent than communicative potentially Constructivist practice.
\end{abstract}

Keywords: teacher beliefs, COLT (Communicative Orientation of Language Teaching) Observation Scheme, Constructivist, Traditional

\section{Teacher Beliefs and Practices}

Teachers' beliefs are such powerful forces in teachers' decisions and actions that they have been said to also influence learner achievement. In other words, teachers' beliefs are linked to student performance (Good, 1987). In some cases, academic failure of students has been attributed to teachers' expectations of students. Sometimes teachers hold low expectations of their students, which can become a self-fulfilling prophecy because the teacher's behaviors, classroom decisions and activities are guided by those beliefs. It has been argued that because they hold low expectations for their students, teachers in low ability classrooms prepare low quality materials and exhibit low quality of teaching. Woolfolk (2004) indicates that "Low-ability classes tend to receive lower-quality instruction in general. Teachers emphasize lower-level objectives and routine procedures, with less academic focus" (p. 116). According to Good and Brophy (2003) this is because:

In planning for and interacting with students, teachers are guided by their beliefs about what students need and by their expectations about how students will respond if treated in particular ways. Also, teachers' beliefs about the academic ability of the class or of individual students may influence their curricular, instructional, or evaluative decisions (p. 67).

Similarly, Miller and Satchwell (2006) claim that: 
Teachers' beliefs about students' potential academic achievement are shaped by their beliefs about the nature of knowledge and the nature of learning and, in relation to our specific interests, their beliefs about the nature of literacy (p. 138).

Yet, there is a need for research studies investigating to see if/to what extent teachers' beliefs have a significant effect on pupil achievement.

In the act of learning and teaching, teachers' beliefs about what learning is, how learners learn best, who the ideal teacher is, who the ideal learner is and about other factors related with learning and teaching might determine their classroom actions. For this reason, Williams and Burden (2007) suggest that:

If the teacher-as-educator is one who is constantly re-evaluating in the light of new knowledge his or her beliefs about language, or about how language is learned, or about education as a whole, then it is crucial that teachers first understand and articulate their own theoretical perspectives (p. 57).

Since teachers' beliefs about them are influential in their pedagogical and methodological choices, decisions and actions, there is a need for shedding light on the network among learners, learning and teaching in the learning and teaching process.

\section{Learners, Learning and Teaching}

Teachers' beliefs about learners and teaching are inextricably linked. For instance, Meighan R. and Meighan J. (1990) categorize teachers' constructions of learners and how they teach in relation to these constructions. They argue that teachers who see learners as "resisters" or "receptacles" or "raw material", teach in a teacher-centered way. However, teachers who see learners as "clients" or "partners" or "individual explorers" or "democratic explorers", teach in a learner-centered way since learners are regarded to be active rather than passive. In the process of learning and teaching, the roles that teachers adopt are consistent not only with their own beliefs but also with their professional context. In a study, Richards et al. (1991) found that Hong Kong English teachers' beliefs about their classroom role were that they should:

(1) provide useful learning experiences, (2) provide a model of correct language use, (3) answer learners' questions, and (4) correct learners' errors. They also believed that their main role as English teachers was to (1) help students discover effective approaches to learning, (2) pass on knowledge and skills to their pupils, and (3) adapt teaching approaches to match their students' needs (cited in Richards \& Lockhart, 2000, p. 37).

In summary, since professional context in Hong Kong requires teachers to adopt Traditional roles in their classes, Hong Kong teachers perceived their roles as to provide a correct model for the students, answer their questions, correct learners and transmit their knowledge to the students.

Traditional and Constructivist perspectives of education exhibit differences in many aspects in terms of learning and teaching. As illustrated in Figure 1, below, Kohonen (1992) compares Traditional and Constructivist Models of Education in terms of teachers' view of learning, power relations in class, teachers' role, students' role, view of knowledge, view of curriculum, learning experiences, control of process, motivation and evaluation. Figure 1, below, illustrates how Traditional and Constructivist Models of Education are different from each other in many ways and how teachers' views of teaching and learning can shape classroom instruction.

According to Figure 1, for example, if the teacher believes in knowledge transmission, she/he provides mainly frontal instruction to the students and she/he is the authority in the class. Learning is teacher-structured. Learning experiences students get are based on knowledge of facts, concepts and skills and the focus is on content and production. Learners are seen as passive recipients of information and they are mainly expected to work individually. Knowledge is presented as "certain" and the curriculum has a predefined content. Learners are mainly extrinsically motivated and the evaluation of students' learning is product-oriented. However, if the teacher believes that learning can be provided through transformation of knowledge, she/he facilitates learning mostly in small groups and favors collaboration, and active participation of learners is important. Learning is self-directed.

Emphasis is on learners, on process, learning skills, self-inquiry, social and communication skills. In terms of power relations, the teacher is seen as a "learner among learners" and construction of personal knowledge is emphasized. Curriculum is seen as dynamic and learners are mainly intrinsically motivated. Unlike a Traditional model of education, evaluation of students' learning is process-oriented. In other words, teachers, whose view of teaching and learning is Traditional, are very much in control of the instructional process and prefer to devote much more time to engage students with high-structure tasks (i.e., in which teachers have all the power and control (Nunan \& Lamb, 1996; cited in Nunan, 1999)). On the other hand, in Constructivist classrooms, although 
high-structure tasks are not totally avoided, students work with low-structure tasks (i.e., in which power and control are devoted to the students (Nunan \& Lamb, 1996; cited in Nunan, 1999)) for most of the learning time. This illustrates how teachers' beliefs are likely to have an impact on teachers' practice. It is believed that a teacher may follow both since these two models are not so absolutely dichotomous.

\section{Methodology}

This study aims to explore the fit between EFL teachers' beliefs and classroom practice in terms of Constructivist learning and teaching in Cyprus Turkish State Secondary Schools.

For this purpose, interviews and observations were employed with purposively selected participants to help the researcher gain a more in-depth understanding about the teachers' beliefs, their perceived practice and actual classroom practice.

\begin{tabular}{|c|c|c|}
\hline Dimension & $\begin{array}{l}\text { Traditional Model: } \\
\text { Behaviorism }\end{array}$ & $\begin{array}{l}\text { Experiential Model: } \\
\text { Constructivism }\end{array}$ \\
\hline 1. View of Learning & Transmission of knowledge & Transformation of knowledge \\
\hline 2. Power Relation & Emphasis on teacher's authority & $\begin{array}{l}\text { Teacher as "learner among } \\
\text { learners" }\end{array}$ \\
\hline 3.Teacher's Role & $\begin{array}{l}\text { Providing mainly frontal } \\
\text { instruction; professionalism as } \\
\text { individual autonomy }\end{array}$ & $\begin{array}{l}\text { Facilitating learning (largely in } \\
\text { small groups; collaborative } \\
\text { professionalism }\end{array}$ \\
\hline 4.Learner's Role & $\begin{array}{l}\text { Relatively passive recipient of } \\
\text { information; mainly individual } \\
\text { work }\end{array}$ & $\begin{array}{l}\text { Active participation, largely in } \\
\text { collaborative small groups }\end{array}$ \\
\hline 5. View of Knowledge & $\begin{array}{l}\text { Presented as "certain"; } \\
\text { application problem-solving }\end{array}$ & $\begin{array}{l}\text { Construction of personal } \\
\text { knowledge; identification of } \\
\text { problems }\end{array}$ \\
\hline 6.View of Curriculum & $\begin{array}{l}\text { Static; hierarchical grading of } \\
\text { subject matter, predefined content } \\
\text { and product }\end{array}$ & $\begin{array}{l}\text { Dynamic; looser organization of } \\
\text { subject matter, including open } \\
\text { parts and integration }\end{array}$ \\
\hline 7. Learning Experiences & $\begin{array}{l}\text { Knowledge of facts, concepts and } \\
\text { skills; focus on content and } \\
\text { product }\end{array}$ & $\begin{array}{l}\text { Emphasis on process; learning } \\
\text { skills, self-inquiry, social and } \\
\text { communication skills }\end{array}$ \\
\hline 8. Control of process & teacher-structured & $\begin{array}{l}\text { Emphasis on learner; self- } \\
\text { directed learning }\end{array}$ \\
\hline 9. Motivation & Mainly extrinsic & Mainly intrinsic \\
\hline 10. Evaluation & $\begin{array}{l}\text { Product-oriented: achievement } \\
\text { testing; criterion- referencing } \\
\text { (and norm- referencing) }\end{array}$ & $\begin{array}{l}\text { Process- } \text { oriented: reflection on } \\
\text { process, self- } \quad \text { assessment; } \\
\text { criterion- referencing }\end{array}$ \\
\hline
\end{tabular}

Figure 1. Comparison of traditional and constructivist models of education (Kohonen, 1992; cited in Nunan 1999, p. 7)

\subsection{Analysis of the Interview Data}

The audio-recorded interviews were transcribed and reviewed several times to gain full understanding of the interviewees' perceptions pertaining to the research questions. Then, for the purpose of thematic coding, the interview transcripts were read and reread employing color coding (using colored highlighting pens) and marginal note taking techniques (Patton, 2002, p. 463) as a means of identifying the similarities and differences in the data. The codes were developed during the analysis considering the theoretical frameworks I drew on which were: teacher-centered and learner-centered teaching.

\subsection{Observation}

The observations were carried some time after the interviews had been completed. The teachers were observed for the purpose of exploring to what extent their beliefs were reflected in their classroom practice. Structured observations were carried out since I decided in advance what to look for in the observations. For this purpose, the 
COLT (Communicative Orientation of Language Teaching) Observation Scheme was used the data collection instrument.

\subsection{Analysis of the Observation Data}

All the observations were video-recorded since "audio-visual data collection has the capacity for completeness of analysis and comprehensiveness of material" (Cohen et al., 2004, p. 313). The timetable for observations was organized in such a way that it allowed the researcher space for watching the recordings and compiling records by working from the video for every teacher soon after each observation to reflect on and evaluate them. After each video-recording, the researcher watched the lesson observed and tried to analyze the recordings in the light of the themes and topics in the COLT Observation Scheme and the fieldnotes the researcher took during the observations. The field-notes and the recordings helped the researcher to detect the lesson episodes that helped her to elicit data regarding the teacher and learner roles, the nature of tasks and activities, the nature of interaction, whether the lesson was done in a Traditional manner or it contained any Constructivist elements, and whether it had any learner-centered characteristics. Regarding the percentages in the COLT categories, the researcher timed the whole lesson and the researcher calculated the time spend for each subcategory (e.g., the percentage of subcategory "T-C" when calculating percentages regarding the interactions category) that emerged in the lesson in order to divide the total amount of time spent for each subcategory per class into the total amount of class time and multiplying the figure by 100. Then, the researcher combined the data she obtained with the help of the COLT and the field notes to write about the teachers' actual classroom practice by combining the information that the interviews yielded about the teachers' beliefs and their perceived practice in relation to the themes Teacher-centered and Learner-centered teaching.

\section{Findings and Discussion}

\subsection{Teachers' Beliefs, Perceived Practice and Actual Classroom Practice in Relation to Teacher-Centered and Learner-Centered Teaching}

Here, the teachers' beliefs, perceived practice and their actual classroom practice will be discussed altogether.

\subsection{Teachers' Beliefs}

There were differences among the teachers' beliefs regarding "Teacher-centered and Learner-centered Teaching". Most of the teachers (eight) believed in learner-centered teaching and two teachers stated that they believed in both teacher-centered and learner-centered teaching which showed that teachers can possess learner-centered and teacher-centered beliefs at the same time. These differences among the teachers' beliefs might be attributed to the individual differences among the teachers such as experiential backgrounds, qualifications, experience, personality, etc. Further research is needed to uncover the reasons underlying the differences. In relation to teacher-centered and learner-centered teaching, two teachers held both teacher-centered and learner-centered beliefs. This suggests that teachers are able to hold opposing beliefs.

\subsection{Teachers' Perceived Practice}

Regarding teacher-centered and learner-centered teaching, five of the teachers who expressed their beliefs in learner-centered teaching claimed teacher-centeredness in their perceived practice and three of the teachers who also believed in learner-centered teaching claimed that their classroom practice was not learner-centered. Two teachers who expressed their beliefs in following both teacher-centered and learner-centered teaching, differed in their perceived practice as such that one of them claimed her practice as teacher-centered and the other one claimed that he was both teacher-centered and learner-centered in his perceived classroom teaching. The interview data indicated that although the teachers expressed their beliefs in Constructivist learning and teaching, and both Constructivist and Traditional, their perceived practice was Traditional (except one teacher).

\subsection{Actual Practice}

Regarding teachers' actual classroom practice, their lessons seemed to exhibit both learner-centered and teacher-centered characteristics. This showed that teachers are able to exhibit opposing practice. The findings of this study give support to Karavas-Doukas's (1996) study conducted in Greek public secondary schools which revealed that teachers may sometimes exhibit teaching behaviors that are in line with both learner-centered and teacher-centered teaching. The findings of this study showed that Traditional practice was more frequent than Communicative potentially Constructivist practice. These findings confirmed Karavas-Doukas's (1996) study who also found that although teachers tended to be eclectic in their teaching, Traditional practice was more frequent than Communicative practice and most of the lessons were teacher-fronted with explicit forms focused instruction in which the language syllabus and the coursebook are structured around language forms and one of the 
principles of the course is learning these forms (Harmer, 2007). The qualitative findings revealed that regarding teacher-centered and learner-centered teaching, teachers showed some variations in their stated beliefs.

The analysis of the interview data, observation data and the field notes revealed that all of the teachers in the study expressed their favor in learner-centered teaching. When the teachers' ideal beliefs, perceived practice and actual classroom practice were considered some variations were noted. As a result of the analysis, the researcher decided to group the teachers under three categories. The first category included the five teachers (Simon, Eleanor, Janette, Sue, James) who believed in learner-centered teaching and whose perceived practice and actual classroom practice were teacher-centered. In the second category, there were three teachers (Carol, Tom, John) who expressed their belief in learner-centered teaching and perceived their practice is not learner-centered. Their actual classroom teaching exhibited a mixture of learner-centered and teacher-centered teaching. The third category included two teachers (Richard and Jessica) who expressed their belief in both learner-centered and teacher-centered teaching. Richard perceived himself to be doing both in his lessons depending on the topic and his actual classroom practice was teacher-centered. Jessica perceived her practice as teacher-centered and her actual practice was also teacher-centered. The teachers' reasons for these discrepancies were stated as: learner characteristics, practical classroom realities (large classes, mixed ability classes, classroom culture, work culture and the curriculum), management problems.

\section{Discussions and Conclusions}

The findings of this study confirmed the findings of earlier studies that showed inconsistencies between beliefs and practice (e.g., Calderhead, 1996; Ertmer, Gopalakrishnan, \& Ross, 2001; Fang, 1996; Kane et al., 2002; Hativa et al., 2001). The findings showed that there were discrepancies among teachers' beliefs, perceived practice and actual classroom practice in most cases. This mismatch between the teachers' stated beliefs and their actual classroom practice might mean that the teachers actually hold Traditional beliefs but they might think that what they ought to express is Constructivist beliefs since the new curriculum is based on Constructivist and learner-centered language learning and teaching principles. Another interpretation might be that the teachers are in favour of Constructivist beliefs but since they have not developed the needed craft knowledge for Constructivist practices they exhibit Traditional teaching.

Although most of the teachers stated their belief in adopting both Traditional and Constructivist roles while the others favoured merely Constructivist roles, they all claimed to be adopting Traditional roles in their perceived classroom practice. However, their actual classroom data revealed that most of the teachers exhibited Traditional roles while some seemed to be adopting both Traditional and Constructivist roles.

It is surprising to find that none of the teachers perceived their practice as Constructivist. This shows that the teachers were aware that their perceived practice was not Constructivist. This might be because the teachers did not possess Constructivist practical knowledge or another interpretation might be that they have not developed the necessary skills to cope with the challenges of hot-spots (e.g., conflicts) (Woods, 1996).

Regarding teacher-centered and learner-centered teaching, half of the teachers stated that they believed in learner-centered teaching and claimed their perceived classroom practice as teacher-centered. In line with their perceived practice, in their actual classroom practice they also exhibited teacher-centered characteristics. Some teachers stated that they believed in learner-centered teaching and they claimed that their perceived practice was not learner-centered. The observational data for these teachers revealed that their lessons were examples to a mixture of both teacher-centered and learner-centered teaching. Some teachers, on the other hand, believed in both teacher-centered and learner-centered teaching. In their perceived practice one of them claimed that in his perceived classroom practice he uses both and the observational data revealed Traditional characteristics. The other teacher was congruent in her perceived practice and actual classroom practice as both being Traditional.

Some teachers seemed to be consistent while some others seemed to be inconsistent regarding their teachers' perceived practice and actual classroom practice. A possible interpretation of the inconsistency in teachers' perceived practice and actual practice might be that when teachers stated their perceived practice they drew on technical knowledge rather than practical knowledge (Eraut, 1994; Ellis, 1997). On the other hand, when the teachers confronted with classroom context they drew on their practical knowledge. Basturkmen et al. (2004) suggested that "over time teachers will be able to proceduralize their technical knowledge, thus making it more accessible. In such cases, the inconsistencies may disappear with experience" (p. 267). However, Eraut (1994) stated that such proceduralization does not often occur.

The findings of this study support both views that the inconsistencies between perceived practice and actual practice may disappear and that the proceduralization does not often occur. When only the teachers' perceived 
practice and actual practice compared, most of the teachers (six) seemed to be consistent regarding classroom activities because their perceived practice and actual practice were Traditional. Similarly, most of the teachers (seven) seemed to be consistent in their perceived practice and actual practice regarding teacher's and learner's role as being Traditional. In relation to teacher-centered and learner-centered teaching, six teachers seemed to be consistent in their perceived practice and actual practice as both being teacher-centered.

The teachers who showed inconsistencies probably drew on their technical knowledge rather than on their practical knowledge. It is also possible that these teachers could not integrate technical knowledge and practical knowledge. Another possibility might be that these teachers were not aware of the inconsistencies.

These inconsistencies between perceived and actual practice would be considered as the hot-spots (Woods, 1996) that are challenges for teachers. For example, these teachers will need to find out how to make their lessons more learner-centered and Constructivist. The discrepancies between teachers' beliefs and actual classroom practice found in most of the teachers might be due to situational constraints because mismatches are usually attributed to situational constraints (Oskamp, 1991; Vaughan \& Hogg, 1998).

This mismatch might be because of the discourse-oriented determinants of action such as the duties, norms and opportunities in their school context and the practical classroom realities which may prevent teachers from implementing their actual beliefs. However, the teachers were well aware of the inconsistency between their beliefs and actual classroom practice which was due to the contextual constraints in their view. According to the teachers, the main impediments to the implementation of their beliefs in their classroom teaching were overly large classes, mixed ability classes, classroom culture, work culture and the curriculum.

The findings of this study give support to the earlier studies discussing the influence of context on teachers' practice (e.g., Borg, 1998, 1999; Golombek, 1998; Mangubhai, Marland, \& Dashwood, 2005; Fang, 1996; Phipps \& Borg, 2009; Ertmer et al., 2001). In a study by Özgün-Koca and Şen (2006), 51 senior secondary pre-service mathematics and physics teachers in Turkey also indicated that contextual constraints prevented them from implementing learner-centered classroom practice. In that respect, it was reported that "Some of the pre-service teachers who advocated a student-centered environment in theory mentioned that they could not bring the theory into life in their student teaching and full-time teaching" (p. 956) because of "crowded classrooms, the differences in students levels of readiness and previous knowledge, insufficient time for applications, and students who are not accustomed to these kinds of environments (pp. 956-957).

In the present study, confirming Özgün-Koca and Şen's (2006) findings, all the teachers stated that overly large classes was an impediment to learner-centered teaching. In the observed classes, as stated earlier, the number of students ranged from 22 to 37 . In learner-centered language classes interaction is a requirement for the development of communication skills obtained through pair work and group work activities because, as Leung (2005) argues:

Interaction offers learners an opportunity to use and work out meaning even when the actual language forms encountered maybe beyond their current level of linguistic competence. In general, then, the idea of communicating with others is often seen as a pedagogic device and "communication" as a bounded phenomenon of language-learning activity (p. 136).

Teachers can face with classroom management problems when teaching a language communicatively in very large classes. In the observed lessons, two female teachers (Sue and Janette) experienced classroom management problems which prevented them from teaching. The problems that Janette experienced in her class could be due to her having the most crowded class of all the teachers. In Sue's class, classroom management problems could be attributed to the learner characteristics, as she expressed it herself, because it included repeat students. It seemed that whatever the challenges, the teachers did not have the necessary skills to overcome them. This situation made them feel disempowered and possibly deskilled.

In that respect, it could be argued that classroom realities shape teachers' classroom practice. Learners' actions and the feedback received from the students regarding the activities and the tasks the teacher uses in class can have impact on the teachers' further actions and teaching in class. This could be well understood from Johnson's (1994) study with four ESL teachers which showed that although the teachers wanted to implement learner-centered teaching, classroom constraints and issues related to classroom management resulted in more teacher-centered teaching. Similarly, Freeman's (1991) study with four EFL teachers revealed that issues related to classroom management with class sizes of 20-30 adolescents resulted in discipline problems and required teachers to provide more control and discipline. Gorsuch's (1998) study which was based on the observation of two high school English classes in Japan also revealed supporting evidence for the influence of contextual constraints on teachers' 
practice. In Gorsuch's (1998) study, it was reported that the participant teachers maintained strong control over the activities because of the large class size and the necessity of keeping pace with the other classes.

Although the teachers expressed their awareness of the mismatch between their beliefs and their practice due to contextual constraints, an alternative interpretation is possible. It could be that these teachers did not really believe in learner-centered classroom practice but pretended to do so since it is a requirement of the Ministry and the administrators in the school. Perhaps, since the teachers also were educated through Traditional practice they were in favour of teacher-centered teaching. It could be difficult for the teacher who is used to a Traditional way of learning and teaching to readily accept a Constructivist view and relevant practice. As a result, as stated by Argyris and Schön (1980), the teachers' espoused theories (theories of what they say) were inconsistent with their theories-in-use (theories of what they do). These two theories may or may not be consistent and a teacher may or may not be aware of any inconsistency between them. However, how to resolve this problem is unclear yet. It is possible that the mismatch between espoused theories and theories-in-use can be resolved through gaining experience in teaching.

\section{Implications}

The findings of this study provide insights into the nature of EFL teachers' beliefs and perceived practice and actual classroom practice in the Cyprus Turkish state secondary schools context to a certain extent. The findings of this study contribute to our understanding of teacher cognition in EFL teaching and learning. It also has impacts on theoretical and methodological assumptions about teacher education and teacher development (i.e., teacher training). It showed the importance of understanding teachers' beliefs and their practical knowledge in teacher education and has the potential to help educators develop an understanding of teacher behaviors, classroom decisions and actions for the purpose of furnishing EFL classrooms with effective teachers in the Cyprus Turkish EFL context. This study also yielded evidence in advancing our understanding of how compatible the teachers' beliefs and practice were with Communicative Language Teaching and thus potentially with Constructivist view of learning and teaching in Cyprus Turkish secondary state schools context. It has also provided evidence to increase our understanding of how and to what extent teachers' practical frameworks for EFL learning and teaching are influential in the implementation of the educational practices within the new Cyprus Turkish Education System. Although generalizations cannot be made for the whole EFL teachers working in Cyprus Turkish secondary schools contexts, to a certain extent it helped me to draw a picture of English language teaching in the state schools and understand at least some of the reasons for the problems in foreign language education in Cyprus Turkish EFL context. This findings of this study showed that beliefs do not always translate into practice, and teachers' beliefs, perceived practice and actual classroom practice might differ. The discrepancy between the beliefs and practice was attributed to contextual constraints by most of the teachers in this study. For this reason, there is a need for further investigation to explore the underlying reasons of any discrepancies between beliefs and practice. This study has also provided empirical evidence to clarify craft knowledge-belief relationship. Further investigations are needed to explore how teachers can be helped to construct and/or develop the needed craft knowledge for their contexts of instruction and how they be supported to integrate their beliefs into their craft knowledge in their existing teaching contexts since the participant teachers in this study seemed to be in such a need. The interviews and the observations were carried out with a relatively small number of EFL teachers and thus the results of the study must be interpreted with caution. In particular, a larger sample of EFL teachers could better represent the diversity of EFL teachers' beliefs and practice which would be desirable. Besides, in this study, the teachers were interviewed and observed only once. Therefore, further studies focusing gathering data on more than one observation and interview are needed to be conducted.

\section{References}

Argyris, C., \& Shön, D. A. (1980). Inner Contradictions of Rigorous Research. New York: Academic Press.

Basturkmen, H., Loewen, S., \& Ellis, R. (2004). Teachers' stated beliefs about incidental focus on form and their classroom practices. Applied Linguistics, 25, 243-272. https://doi.org/10.1093/applin/25.2.243

Borg, S. (1998). Teachers' pedagogical systems and grammar teaching: A qualitative study. TESOL Quarterly, 32(1), 9-38. https://doi.org/10.2307/3587900

Borg, S. (1999). The use of grammatical terminology in the second language classroom: A qualitative study of teachers' practices and cognitions. Applied Linguistics, 20(1), 95-126. https://doi.org/10.1093/applin/20.1.95

Calderhead, J. (1996). Teachers: Beliefs and knowledge. In D. Berliner, \& R. Calfee (Eds.), Handbook of Educational Psychology (pp. 709-725). New York. 
Cohen, L., Manion, L., \& Morrison, K. (2004). Research Methods in Education (5th ed.). Routledge Falmer: London and New York.

Ellis, R. (1997). SLA Research and Language Teaching. Oxford: Oxford University Press.

Eraut, M. (1994). Developing Professional Knowledge and Competence. London: Falmer.

Ertmer, P. A., Gopalakrishnan, S., \& Ross, E. M. (2001). Technology-using teachers: Comparing perceptions of exemplary technology use to best practice. Journal of Research on Technology in Education, 33(5). Retrieved June, 2000, from http://www.iste.org/jrte/33/5/ertmer.html

Fang, Z. (1996). A review of research on teacher beliefs and practices. Educational Research, 38(1), 47-65. https://doi.org/10.1080/0013188960380104

Freeman, D. (1991). "To make the tacit explicit": Teacher education, emerging discourse, and conceptions of $\begin{array}{lllll}\text { teaching. Teaching and Teacher } & \text { Education, }\end{array}$ https://doi.org/10.1016/0742-051X(91)90040-V

Golombek, P. R. (1998). A study of language teachers' personal practical knowledge. TESOL Quarterly, 32(3), 447-464. https://doi.org/10.2307/3588117

Good, T. L. (1987). Teacher expectations. In D. C. Berliner, \& B. V. Rosenshine (Eds.), Talks to Teachers (pp. 159-200). New York: Random House.

Good, T. L., \& Brophy, J. E. (2003). Looking in Classrooms (9th ed.). Allyn \& Bacon: USA.

Gorsuch, G. J. (1998). Yakudoku EFL instruction in two Japanese high school classrooms: An exploratory study. JALT Journal, 20, 6-32.

Harmer, J. (2007). The Practice of English Language Teaching (4th ed.). Pearson Education: UK.

Hativa, N., Barak, R., \& Simhi, E. (2001). Exemplary university teachers: Knowledge and beliefs regarding effective teaching dimensions and strategies. Journal of Higher Education, 72, 699-729. https://doi.org/10.1080/00221546.2001.11777122

Johnson, K. E. (1994). The emerging beliefs and instructional practices of pre-service English as a second language teachers. Teachers and Teacher Education, 10(4), 439-452. https://doi.org/10.1016/0742-051X(94)90024-8

Kane, R., Sandetto, S., \& Heath, C. (2002). Telling half the story: A critical review of research on the teaching beliefs and practices of university academics. Review of Educational Research, 72, 177-228. https://doi.org/10.3102/00346543072002177

Karavas-Doukas, E. (1996). Using attitude scales to investigate teachers' attitudes to the Communicative Approach. ELT Journal, 50(3), 187-198. https://doi.org/10.1093/elt/50.3.187

Kohonen, V. (1992). Experiential language learning: Second language learning as cooperative learner education. In D. Nunan (Ed.), Collaborative Language Learning and Teaching. Cambridge: Cambridge University Press.

Leung, C. (2005). Convivial communication: Recontextualizing communicative competence. International Journal of Applied Linguistics, 15(2), 119-144. https://doi.org/10.1111/j.1473-4192.2005.00084.x

Mangubhai, F., Marland, P., Dashwood, A., \& Son, J. B. (2005). Similarities and differences in teachers' and researchers' conceptions of communicative language teaching: Does the use of an educational model cast a better light? Langauge Teaching Research, 9(1), 31-66. https://doi.org/10.1191/13621688051r153oa

Meighan, R., \& Meighan, J. (1990). Alternative roles for learners with particular reference to learners as democratic explorers in teacher education courses. The School Field, 1(1), 61-77.

Miller, K., \& Satchwell, C. (2006). The effect of beliefs about literacy on teacher and student expectations: A further education perspective. Journal of Vocational Education and Training, 58(2), 135-150. https://doi.org/10.1080/13636820600799551

Nunan, D. (1999). Second Language Teaching. Heinle \& Heinle Publishers, USA.

Nunan, D., \& Lamb, C. (1996). The Self-Directed Teacher. Cambrigde: Cambridge University Press.

Oskamp, S. (1991). Attitudes and Opinions. Sydney: Prentice Hall. 
Özgün-Koca, S. A., \& Şen, A. İ. (2006). The beliefs and perceptions of pre-service teachers enrolled in a subject-area dominant teacher education program about "Effective Education". Teaching and Teacher Education, 22, 946-960. https://doi.org/10.1016/j.tate.2006.04.036

Patton, M. Q. (2002). Qualitative Evaluation and Research Methods (3rd ed.). Sage Publications: CA, USA.

Phipps, S., \& Borg, S. (2009). Exploring tensions between teachers' grammar teaching beliefs and practices. System, 37, 380-390. https://doi.org/10.1016/j.system.2009.03.002

Richards, J. C., Tung, P., \& Ng, P. (1991). The culture of the English language teacher: A Hong Kong example. Department of English Research Report No. 6, City Polytechnic of Hong Kong.

Richards, J., \& Lockhart, C. (2000). Reflective Teaching in Second Language Classrooms. Cambridge University Press, China.

Vaughan, M., \& Hogg, M. M. (1998). Introduction to Social Psychology. Sydney: Prentice Hall.

Williams, M., \& Burden, R. L. (2007). Psychology for Language Teachers. UK: Cambridge University Press.

Woods, D. (1996). Teacher Cognition in Language Teaching: Beliefs, Decision-making and Classroom Practice. UK: Cambridge University Press.

Woolfolk, A. (2004). Educational Psychology (9th ed.). Allyn \& Bacon: USA.

\section{Note}

Note 1. This paper consists of a part of the EdD thesis conducted by Sibel Ersel Kaymakamoğlu who was supervised by Dr. Agneta Svalberg.

\section{Copyrights}

Copyright for this article is retained by the author(s), with first publication rights granted to the journal.

This is an open-access article distributed under the terms and conditions of the Creative Commons Attribution license (http://creativecommons.org/licenses/by/4.0/). 